\title{
微小振幅波理論に基づく波長の 近似計算式の相互比較 COMPARATIVE STUDY OF VARIOUS EXPLICIT SOLUTIONS TO DISPERSION EQUATION IN THE AIRY WAVE THEORY
}

\author{
山口正隆 ${ }^{1} \cdot$ 野中浩一 $^{2}$ \\ Masataka YAMAGUCHI and Hirokazu NONAKA \\ ${ }^{1}$ 正会員 工博 愛媛大学大学院理工学研究科教授 生産環境工学専攻 ( T 790-8577 松山市文京町 3) \\ ${ }^{2}$ 正会員 博(工学) 愛媛大学契約職員 工学部環境建設工学科 (†790-8577 松山市文京町 3)
}

\begin{abstract}
The dispersion equation in the Airy wave theory is a transcendental equation, which usually requires an iterative technique to obtain a numerically exact solution of wave length for a given wave period and water depth. As an alternative, various kinds of approximate and explicit solutions have been proposed. This paper presents the results of a comparative study of the error relative to the exact solution for each of 25 explicit solutions with different degree of accuracy including 10 new ones. The conclusions are as follows ; 1) In the case of explicit solutions valid for a whole range of water depth conditions, one of the solutions proposed in this study with an error of less than $\pm 0.0001 \%$ is more proper than the others in its accuracy and compactness of the solution. 2) Neither of the explicit solutions applicable to a restricted water depth condition may be preferable for the sake of inconvenience associated with the restrictive condition in spite of its relatively higher accuracy within an applicability range.
\end{abstract}

Key Wbr ds : wave dispersion equation, exact solution, approximate solutions, comparative study

\section{1. 緒 言}

一定水深上の微小振幅波理侖に基づく波長 $L$ ，周期 $T$ ， 水深 $h$ の関係は周知の分散関係式により与えられる . 分 散関係式は波長 $L$ に関する超越方程式であるので, 弚の 解を得るために反復計算法を用いる必要がある . パソコ ンの高性能化か実現された今日, 反復計算法の適用は浅 海波浪推算のように膨大なケースの計算を行う場合を除 き, 計算時間の面で実用上ほとんど問題にならない．し かし, 波理侖の基本を構成する分散関係式の解陽形式 で表されない点は初学者にとって波理論を取り組みにく いものにしており，したがって学習上あるいは教育上の 障壁となっていると考える . 兴のため, 代替方法として これまでに波長に対する多種多樣の近似計算式力提案さ れている、また, Fenton and McKee ${ }^{1}$ は 1990年以前の9 種類の近似式の精度を, $\mathrm{You}^{2}$ は 2002 年の $\mathrm{Guo}^{3}$ の式を含 む 5 種類の近似式の精度を相互比較している。

本研究では, Newton法による数值解を准厳密解とする ことによって，従前の各近似式の誤差の範囲を明確にす るとともに 精度の異なる各種の近似式を新たに提案し， 乥れ光れの精度を包括的に明らかにする。

\section{2 . 波長計算式と数値計算法}

波長 $L$ と周期 $T$ ，水深 $h$ の関係は次式で表される .

$$
L=\left(\frac{g T^{2}}{2 \pi}\right) \tanh \frac{2 \pi h}{L}=L_{0} \tanh \frac{2 \pi h}{L}, \quad L_{0}=\frac{g T^{2}}{2 \pi}
$$

ここに, 添字 。は深每波， $g$ は重力加速度を意味する。

これを波数 $k=2 \pi / L ， k_{0}=2 \pi / L_{0}$ で表示すると，

$$
k_{0} h=k h \cdot \tanh k h
$$

である.ここで，

$$
\alpha=k_{0} h=2 \pi\left(h / L_{0}\right)=(2 \pi / T \sqrt{g / h})^{2}
$$

とすれば，式(2)は次式のように置ける .

$$
\alpha=k h \cdot \tanh k h=\beta \cdot \tanh \beta, \quad \beta=k h
$$

式(4)の数值解を得るために Newton 法を適用すれば, 計 算に用いるべき式は次式になる .

$$
\begin{aligned}
& f\left(\beta_{n}\right)=\alpha-\beta_{n} \tanh \beta_{n}, \\
& f^{\prime}\left(\beta_{n}\right)=-\tanh \beta_{n}-\beta_{n} \operatorname{sech}^{2} \beta_{n},
\end{aligned}
$$




$$
\begin{aligned}
& \beta_{n+1}=\beta_{n}-f\left(\beta_{n}\right) / f^{\prime}\left(\beta_{n}\right), \\
& \left|\left(\beta_{n+1}-\beta_{n}\right) / \beta_{n}\right|<\varepsilon, \quad \varepsilon=10^{-10}
\end{aligned}
$$

ここに，添字“，'は微分を，添字“ n'は繰り返し回 数を表す. 初期值として

$\beta_{0}=\alpha=2 \pi\left(h / L_{0}\right) ; \alpha \geq 1$ or $h / L_{0} \geq 1 / 2 \pi$ ，

$\beta_{0}=\alpha^{1 / 2}=\left\{2 \pi\left(h / L_{0}\right)\right\}^{1 / 2} ; \alpha<1$ or $h / L_{0}<1 / 2 \pi$

\section{を利用する。}

合田 ${ }^{4), 5}$ (は式(5)の第 1 式における変曲点 $\left(f^{\prime \prime}(\beta)=0\right.$,

$\beta \cdot \tanh \beta=1, \beta \approx 1.200)$ の出現を避けるため，

$$
f\left(\beta_{n}\right)=\beta_{n}-\alpha \cdot \operatorname{coth} \beta_{n}
$$

を使用することを推奨している．また，式(5)の第 1 式は 次式のようにも書ける.

$$
f\left(\beta_{n}\right)=\alpha / \beta_{n}-\tanh \beta_{n}
$$

この式も変曲点をもたない $. h / L_{0}=10^{-6} \sim 1 \quad\left(10^{-6}\right.$ きざ み)ては,式(5),式(7),式(8)いずれの式もすべての $h / L_{0}$ て同じ解を与え, 数值計算上の問題を生じなかった。

\section{3. 波長の近似計算式と光の精度}

\section{（1）波長の近似計算式の分類と誤差基準}

これまでに提案された波長に対する各種の近似計算式 は, I $: h / L_{0}$ の全範囲に有効な式, $\|: h / L_{0}$ の限られ た範囲に有効な式，の 2 グループに大別され，さらに光 れ光れは，(1)精度は相対的に低いか试の形か簡潔である 式 , (2)精度は高いか形か複雑な式あるいは長い項をもつ 式，の2 グループに分類される . また , Iグループに属 する式は炎の適用範囲により i ) 浅海域用，ii ）准深海 域用，に分けられる。

各種の近似計算式の准厳密解に対する相対誤差は， $h / L_{0}=10^{-4} \sim 1$ (10-4のきざみ) の条件のもとに , 添字“ $a^{\prime}$ を近似解; exa'を Newton法による准厳密解として

$$
\tilde{\varepsilon}=\left(L_{a} / L_{\text {exa }}-1\right) \times 100 \%
$$

で表示する。

（2）相対水深の全領域に適用可能な近似式

I (1)グループに属する各式と光の相対誤差の範囲は精 度の低い順に ,つぎのように書ける。

1) Eckart ${ }^{6} の$ 式

$$
\begin{aligned}
& k_{a} h=\beta_{a}=\alpha(\operatorname{coth} \alpha)^{1 / 2}, k_{a}=2 \pi / L_{a} \\
& \tilde{\varepsilon}=0 \sim 5.24\left(h / L_{0}=0.111\right) \%
\end{aligned}
$$

式(11)の（ ) 内の数值は相当する誤差をもたらすときの $h / L_{0}$ の值を表す .

2) 岩垣 ${ }^{7} の$ 式

$$
\beta_{a}=\alpha \cdot \operatorname{coth}\left\{\alpha^{1 / 2}\left(1+\alpha^{1 / 2} / 2 \pi\right)\right\}
$$

$$
\tilde{\varepsilon}=-3.05\left(h / L_{0}=0.287\right) \sim 3.14\left(h / L_{0}=0.023\right) \%
$$

3) Carvlho ${ }^{8)}$ 第 14 式 (Carv14 と略記)

$$
\beta_{a}=\alpha\left(1+\alpha^{-2}\right)^{1 / 4}
$$

$$
\tilde{\varepsilon}=-2.45\left(h / L_{0}=0.366\right) \sim 3.28\left(h / L_{0}=0.068\right) \%
$$

$\mathrm{Carvlho}^{8}{ }^{8}$ がちえた式番号に従って 上式を第14式と呼ぶ． 以下も同樣である.Carvlho ${ }^{8}$ は分散関係式に対する 17 種 類の近似解をまとめている.最大相対誤差の絶対值は 0.012 5.24\%の範囲にある.このうち，上式に加えて第 4 式,第 5 式, 第 9 式は簡潔な式形や各式に相当した相 対的精度の高さの点で注目に值すると考えられる .

4) Fenton and $\mathrm{McKee}^{9}$ の式 (FM と略記)

$$
\beta_{a}=\alpha\left(\operatorname{coth} \alpha^{m / 2}\right)^{1 / m} ; m=1.5
$$

$$
\tilde{\varepsilon}=-1.39\left(h / L_{0}=0.321\right) \sim 1.66\left(h / L_{0}=0.054\right) \%
$$

5) Fenton and $\mathrm{McKee}^{9)}$ の式(16)の修正式，あるいは山 ・野中の第 1 式 (YN1 と略記)

$$
\begin{gathered}
\beta_{a}=\alpha\left(\operatorname{coth}^{m / 2}\right)^{1 / m} ; m=1.485 \\
\tilde{\varepsilon}=-1.52\left(h / L_{0}=0.315\right) \sim 1.55\left(h / L_{0}=0.052\right) \%
\end{gathered}
$$

これは式(16)と基本的に同じであるが, 正負の最大誤差 か洞程度になるようにべき数 $m$ を調整した結果である。 6) Carvlho ${ }^{8)}$ 第 9 式 (Carv9 と略記)

$$
\begin{gathered}
\beta_{a}=\alpha \cdot \operatorname{coth}\left(\sinh \alpha^{1 / 2}\right) \\
\tilde{\varepsilon}=-1.12\left(h / L_{0}=0.237\right) \sim 0 \%
\end{gathered}
$$

7) $\mathrm{Guo}^{3)}$ の式

$$
\begin{gathered}
\beta_{a}=\alpha /\left\{1-\exp \left(-\alpha^{m / 2}\right)\right\}^{1 / m} ; m=2.4901 \\
\tilde{\varepsilon}=-0.75\left(h / L_{0}=0.284\right) \sim 0.75\left(h / L_{0}=0.043\right) \%
\end{gathered}
$$

$\mathrm{Guo}^{3)}$ は $m=2.4908$ または 2.4901 としているが , ここで は正負で同程度の誤差を生じる $m=2.4901$ を用いる。

8) Fenton and McKee" の式の修正式(18)と分散関係式の 結合，あるいは山口・野中の第2式 (YN2 と略記)

$$
\begin{aligned}
& \beta_{a}=\alpha \cdot \operatorname{coth} \beta_{F}, \beta_{F}=\alpha\left(\operatorname{coth} \alpha^{m / 2}\right)^{1 / m} ; m=1.378 \\
& \tilde{\varepsilon}=-0.73\left(h / L_{0}=0.029\right) \sim 0.73\left(h / L_{0}=0.187\right) \%
\end{aligned}
$$

これは山口・野中の第 1 式(18)て得られた值をもとの波 長計算式(4)に代入して, 改めて波長を求めることにより

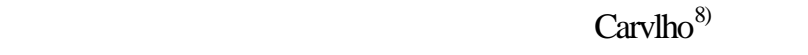
手法を採用している.最大誤差は Fenton and MacKee の 


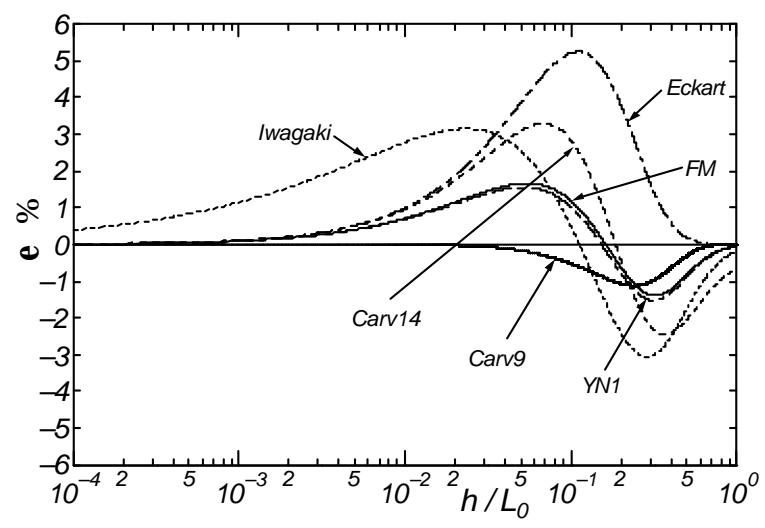

図-1 波長の近似計算式の相対誤差 $\tilde{\varepsilon}$ と $h / L_{0}$ の関係(1)

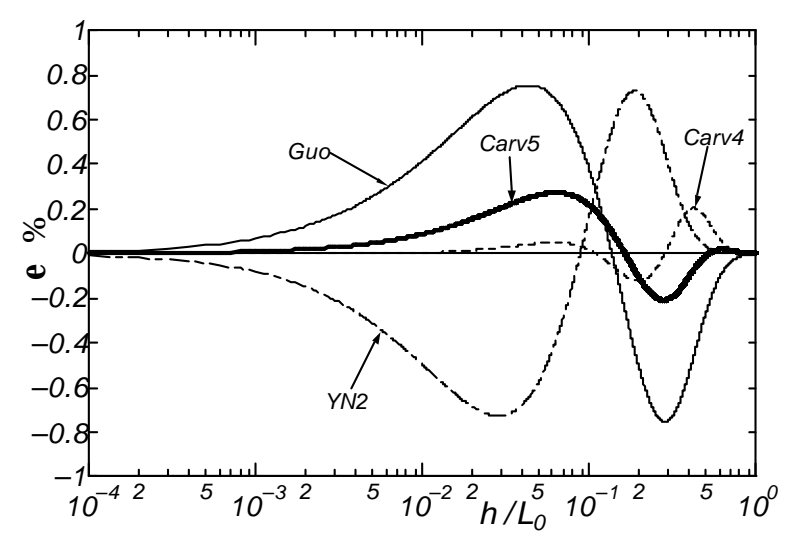

图-2 波長の近似計算式の相対誤差 $\tilde{\varepsilon} と h / L_{0}$ の関係 $(2)$

式(16)や山口・野中の第1 式(18)のほぼ $1 / 2$ になる .べき 数 $m$ は正負の最大誤差か洞程度になるように調整して 得ている . Carvlho ${ }^{8)}$ のうに同樣の操作を繰り返すこと は, 表示式の複杂倠化や誤差縮小の非効率性からみてあま り意味ないと考えられる。

9) Carvlho ${ }^{8)}$ 第 5 式 (Carv5 と略記)

$$
\beta_{a}=\alpha \cdot \operatorname{coth}\left(1.2^{\alpha} \cdot \alpha^{1 / 2}\right)
$$

$$
\tilde{\varepsilon}=-0.21\left(h / L_{0}=0.278\right) \sim 0.27\left(h / L_{0}=0.063\right) \%
$$

10) Carvlho ${ }^{8}$ の第4式 (Carv4 と略記)

$$
\begin{gathered}
\beta_{a}=\alpha /\left\{(\tanh \alpha)^{1 / 4} \cdot\left[\tanh \left\{(\sinh \alpha)^{1 / 2}\right\}\right]^{1 / 2}\right\} \\
\tilde{\varepsilon}=-0.12\left(h / L_{0}=0.198\right) \sim 0.20\left(h / L_{0}=0.423\right) \%
\end{gathered}
$$

$\mathrm{Carvlho}^{8)}$ の第 5 式と第 4 式のうち，第 5 式は簡単な式形 と高い精度からみて, 有力な近似式である. 第4 式はや や高い精度を与えるものの, かなり複雑な形をもつ。

以上に述べた 1)〜10)の各式はいずれも深海波条件 $(\alpha \rightarrow \infty)$ およひ長波条件 $(\alpha \rightarrow 0)$ て紴密解に漸近 する . 図-1は 1)〜6)の各式 , 図-2は 7) 10)の各式によ る相対誤差 $\tilde{\varepsilon}$ の值と $h / L_{0} \quad\left(=10^{4} \sim 1\right)$ の関係を示す.い ずれの式による $气$ も極大值や極小值あるいは光の両者 をとつたのち,$h / L_{0}$ の両極限に向けて 0 に漸近する . 以 上の諸式のうち誤差の大きさや式の簡潔さを考えると， Carvlho ${ }^{8}$ の第 5 式(26) (最大誤差約 $\left.0.3 \%\right)$ が $h / L_{0}$ の全範 囲について適切である。

\section{（3）相対水深の全領域に適用可能な高精度近似式}

I (2)グループに分類され, より高い精度をもつ近似計

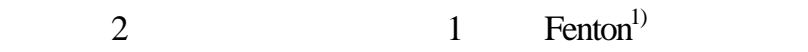
えられたように，分散関係式(4)に Newton 法を適用して 得られる第 1 回目の反復解を用いる方法であり，次式で 表される.

$$
\begin{aligned}
& f\left(\beta_{0}\right)=\alpha-\beta_{0} \tanh \beta_{0}, \\
& f^{\prime}\left(\beta_{0}\right)=-\tanh \beta_{0}-\beta_{0} \operatorname{sech}^{2} \beta_{0}, \\
& \beta_{1}=\beta_{0}-\frac{f\left(\beta_{0}\right)}{f^{\prime}\left(\beta_{0}\right)}=\beta_{0}+\frac{\alpha-\beta_{0} \tanh \beta_{0}}{\tanh \beta_{0}+\beta_{0} \operatorname{sech}^{2} \beta_{0}} \\
& =\frac{\alpha+\beta_{0}^{2} \operatorname{sech}^{2} \beta_{0}}{\tanh \beta_{0}+\beta_{0} \operatorname{sech}^{2} \beta_{0}}=\frac{\alpha+\beta_{0}^{2}\left(1-\tanh ^{2} \beta_{a}\right)}{\tanh \beta_{0}+\beta_{0}\left(1-\tanh ^{2} \beta_{0}\right)} \text { (30) }
\end{aligned}
$$

他の 1 つは Padé 近似による方法である . Newton法によ る反復解を利用する場合 , 1)〜10)の各式を式(30)の $\beta_{0}$ に 代入すればよい .すなわち, Eckart ${ }^{6} の$ 式に対して , 近似 計算式と炎の相対精度の範囲はつぎのように書ける .

11-1) Fenton ${ }^{1)}$ 式、あるいは Eckart $の$ 式(10)に対する 反復解

$$
\begin{gathered}
k_{a} h=\left(\alpha+\beta_{a}^{2} \operatorname{sech}^{2} \beta_{a}\right) /\left(\tanh \beta_{a}+\beta_{a} \operatorname{sech}^{2} \beta_{a}\right) \\
=\left\{\alpha+\beta_{a}^{2}\left(1-\tanh ^{2} \beta_{a}\right)\right\} /\left\{\tanh \beta_{a}+\beta_{a}\left(1-\tanh ^{2} \beta_{a}\right)\right\}, \\
\beta_{a}=\alpha(\operatorname{coth} \alpha)^{1 / 2} \\
\tilde{\varepsilon}=-5.1 \times 10^{-2}\left(h / L_{0}=0.070\right) \sim \\
\quad 8.4 \times 10^{-3}\left(h / L_{0}=0.218\right) \%
\end{gathered}
$$

以下 ,Newton法による反復解は同一であるので, $\beta_{a}$ に 対する式と相対誤差の範囲を記す. 前者も光れ光れ前掲 と同一の式であるが, 異なる係数 $m$ をもつものもある .

11-2) 岩垣 の式(12)に対する反復解，あるいは山口・ 野中の第 3 式 (YN3 と略記)

$$
\begin{aligned}
& \beta_{a}=\alpha \cdot \operatorname{coth}\left\{\alpha^{1 / 2}\left(1+\alpha^{1 / 2} / 2 \pi\right)\right\} \\
& \tilde{\varepsilon}=- 4.0 \times 10^{-2}\left(h / L_{0}=0.019\right) \sim \\
& 1.2 \times 10^{-2}\left(h / L_{0}=0.289\right) \%
\end{aligned}
$$

11-3) Carvlho ${ }^{8)}$ 第 14式(14)に対する反復解，あるいは 山口・野中の第 4 式 (YN4 と略記)

$$
\begin{aligned}
& \beta_{a}=\alpha\left(1+\alpha^{-2}\right)^{1 / 4} \\
& \tilde{\varepsilon}=- 2.9 \times 10^{-2}\left(h / L_{0}=0.053\right) \sim \\
& 6.7 \times 10^{-3}\left(h / L_{0}=0.335\right) \%
\end{aligned}
$$

11-4) Fenton and MacKee'の式の修正式(18)に対する反 復解，あるいは山口・野中の第 5 式 (YN5 と略記)

$$
\beta_{a}=\alpha\left(\operatorname{coth} \alpha^{m / 2}\right)^{1 / m} ; m=1.434
$$




$$
\begin{gathered}
\tilde{\varepsilon}=-4.9 \times 10^{-3}\left(h / L_{0}=0.036\right) \sim \\
4.9 \times 10^{-3}\left(h / L_{0}=0.296\right) \%
\end{gathered}
$$

Fenton and MacKee"の式に対する反復解は正負て絶対値 力潩なる最大誤差の範囲 $\left(\tilde{\varepsilon}=-8.5 \times 10^{-3} \sim 2.3 \times 10^{-2}\right)$ を 与え, 式(37)による反復解より低い精度しかもたないの で，掲載を省略している。

11-5) Carvlho $0^{8)}$ 第9式(20)に対する反復解，あるいは 山口・野中の第6式 (YN6 と略記)

$$
\begin{aligned}
& \beta_{a}=\alpha \cdot \operatorname{coth}\left(\sinh \alpha^{1 / 2}\right) \\
& \tilde{\varepsilon}=- 4 \times 10^{-4}\left(h / L_{0}=0.101\right) \sim \\
& 1.4 \times 10^{-3}\left(h / L_{0}=0.264\right) \%
\end{aligned}
$$

11-6) Guo ${ }^{3)}$ 式(22)の修正式に対する反復解，あるいは 山口・野中の第 7式 (YN7 と略記)

$$
\begin{gathered}
\beta_{a}=\alpha /\left\{1-\exp \left(-\alpha^{m / 2}\right)\right\}^{1 / m} ; m=2.445 \\
\tilde{\varepsilon}=-1.2 \times 10^{-3}\left(h / L_{0}=0.030\right) \sim \\
1.2 \times 10^{-3}\left(h / L_{0}=0.278\right) \%
\end{gathered}
$$

11-7) 山口・野中の第2式(24)に対する反復解，あるい は山口・野中の第 8 式 (YN8 と略記)

$$
\begin{aligned}
\beta_{a}=\alpha \cdot \operatorname{coth} \beta_{F}, \quad & \beta_{F}=\alpha\left(\operatorname{coth} \alpha^{m / 2}\right)^{1 / m} ; m=1.310 \\
\tilde{\varepsilon}=- & 9 \times 10^{-4}\left(h / L_{0}=0.112\right) \sim \\
& 8 \times 10^{-4}\left(h / L_{0}=0.223\right) \%
\end{aligned}
$$

11-8) Carvlho ${ }^{8}$ の第 5 式(26)の修正式に対する反復解， あるいは山口・野中の第9式 (YN9 と略記)

$$
\begin{gathered}
\beta_{a}=\alpha \cdot \operatorname{coth}\left(m^{\alpha} \cdot \alpha^{1 / 2}\right) ; m=1.1965 \\
\tilde{\varepsilon}=-1.1 \times 10^{-4}\left(h / L_{0}=0.044\right) \sim \\
1.1 \times 10^{-4}\left(h / L_{0}=0.274\right) \%
\end{gathered}
$$

11-9) Carvlho ${ }^{8)}$ の第4式(28)に対する反復解，あるいは 山口・野中の第 10 式 (YN10 と略記)

$$
\begin{gathered}
\beta_{a}=\alpha /\left\{(\tanh \alpha)^{1 / 4}\left[\tanh \left\{(\sinh \alpha)^{1 / 2}\right\}\right]^{1 / 2}\right\} \\
\tilde{\varepsilon}=-7 \times 10^{-6}\left(h / L_{0}=0.056\right) \sim \\
4 \times 10^{-5}\left(h / L_{0}=0.401\right) \%
\end{gathered}
$$

上記の 11-4)，11-6)，11-7)，11-8)の中に与えられる各 式は光れ光れ正負の最大誤差の絶対值がほぼ一致するよ うに,べき数 $m$ を調整している.初期值の精度力゙高いほ ど ,Newton 法の第 1 回目の反復解としての最終解の精度 も当然高い.

最大誤差の正負の対称性と精度およひ第 1 次近似式の 簡潔さを考慮すると, Carvlho ${ }^{8}$ の第 5 式の修正式に対す る反復解，あるいは山口・野中の第 9 式，すなわち式(45) を初期值として式(31)の第 1 式より得られる解力最適と 判断される.

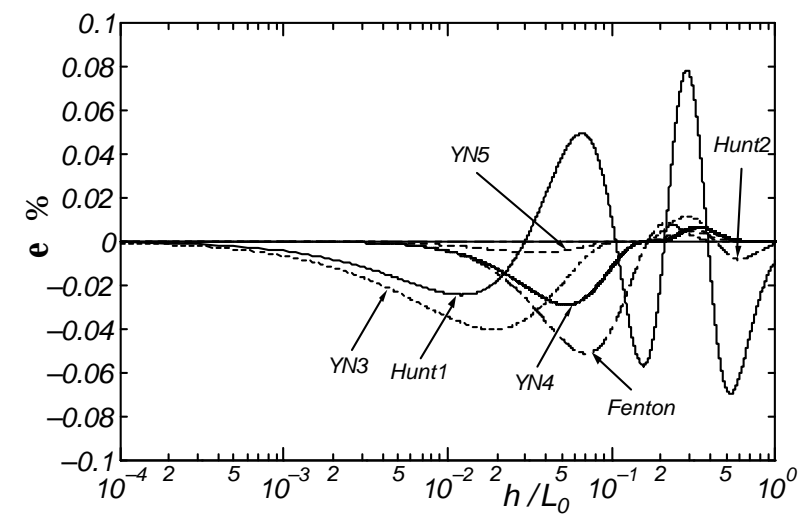

図-3 波長の近似計算式の相対誤差 $\tilde{\varepsilon}$ と $h / L_{0}$ の関係(3)

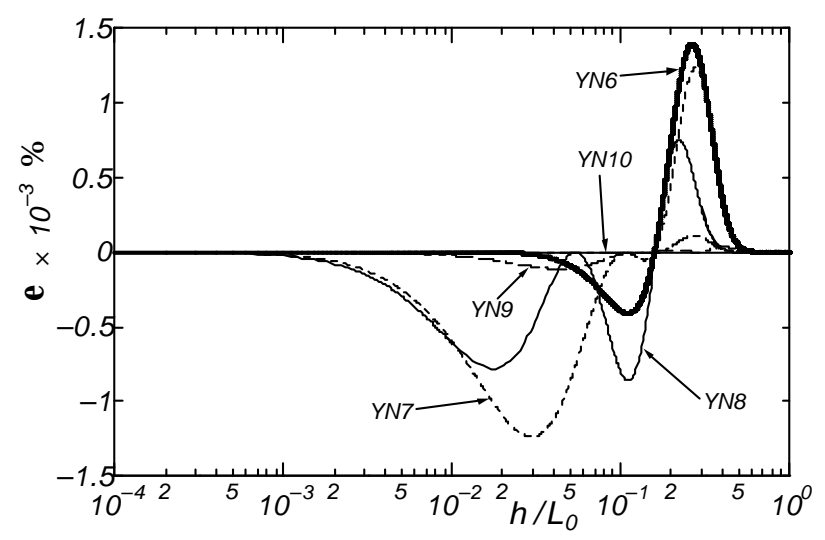

図-4 波長の近似計算式の相対誤差 $\tilde{\varepsilon}$ と $h / L_{0}$ の関係(4)

Padé 近似に基づく Hunt ${ }^{10)}$ の式はつぎのようである . 12) Hunt ${ }^{10)}$ 第 1 式 (Hunt1 と略記)

$$
\begin{gathered}
\left(k_{a} h\right)^{2}=\alpha\left\{\alpha+\left(1+0.6522 \alpha+0.4622 \alpha^{2}\right.\right. \\
\left.\left.+0.0864 \alpha^{4}+0.0675 \alpha^{5}\right)^{-1}\right\} \\
\tilde{\varepsilon}=-7.0 \times 10^{-2}\left(h / L_{0}=0.532\right) \sim \\
7.8 \times 10^{-2}\left(h / L_{0}=0.288\right) \%
\end{gathered}
$$

13) Hunt ${ }^{10)}$ の第 2 式 (Hunt2 と略記)

$$
\begin{gathered}
\left(k_{a} h\right)^{2}=\alpha\left\{\alpha+\left(1+0.66667 \alpha+0.35550 \alpha^{2}+0.16084 \alpha^{3}\right.\right. \\
+0.06320 \alpha^{4}+0.02174 \alpha^{5}+0.00654 \alpha^{6} \\
\left.\left.+0.0017 \mathrm{~b}^{7}+0.00039 \alpha^{8}+0.0001 \mathrm{~b}^{9}\right)^{-1}\right\} \\
\tilde{\varepsilon}=-8.2 \times 10^{-3}\left(h / L_{0}=0.603\right) \sim \\
5.4 \times 10^{-3}\left(h / L_{0}=0.324\right) \%
\end{gathered}
$$

Hunt ${ }^{10)}$ の第 1 式(49)は $\alpha^{5}$ の項まで用いた最大相対誤差 $0.1 \% の$ 近似式，第 2 式(51)は $\alpha^{9}$ の項まで用いた最大相対 誤差 $0.01 \% の$ 近似式となっている.式(51)では，用いられ る項数が多すぎる . また Newton 法による反復解と比べ ると, 弚の精度もあまり高くない。

以上に述へた 11-1)〜13)の各式は 1)〜10)の各式と同樣 に $h / L_{0}$ の両極限において厳密解を満たす .図-3は 11-1)， 11-2)，11-3)，11-4)，12），13)の各式による相対誤差 $\tilde{\varepsilon}$ と $h / L_{0}$ の関係を，また図 4は高精度の近似式である 11-5) 


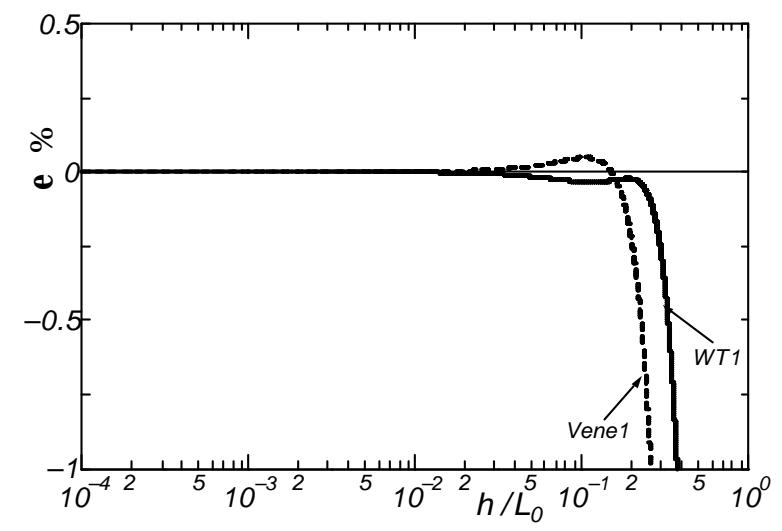

図 5 波長の近似計算式の相対誤差 $\tilde{\varepsilon}$ と $h / L_{0}$ の関係(5)

〜11-9)の各式による相対誤差 $\tilde{\varepsilon}$ と $h / L_{0}$ の関係を示す. 図-3ては Hunt ${ }^{10)}$ の第 5 式(49)による $\widetilde{\varepsilon}$ が0のまわりに大 きい振動を伴う特徵力際立つこと, 図 4では初期值の精 度か高いものほど反復解の精度が $h / L_{0}$ の全範囲につい て高いことがうかがえる。

(4) 浅海域に適用力限定される近似式

浅海域に適用か限定される川グル一プの式のうち，簡 潔な形でしかもある程度の精度をもつ近似式, すなわち (1)グループに属する式 ${ }^{11), 12), 13)}$ のうち Venezian ${ }^{12)}$ 第 1 式と Wu and Thornton ${ }^{13)}$ 第 1 式およびとれぞれの式の相 対誤差の範囲を以下に示す.これらは光れ光れ長波条件 $(\alpha \rightarrow 0)$ に対して厳密解に漸近する . また，いずれの 式による相対誤差 $\tilde{\varepsilon} も h / L_{0}$ の増加とともに一度極值を とったのち負值を急増させるので, 弚の極值と同程度の 絶対值を与える $h / L_{0}$ を各式の適用限界值 $\left(h / L_{0}^{*}\right.$ で表示) としている

14) Venezian ${ }^{12)} の$ 第 1式 (Venel と略記)

$$
\begin{gathered}
k_{a} h=\alpha^{1 / 2} /(1-\alpha / 6) ; h / L_{0}^{*} \leq 0.165 \\
\tilde{\varepsilon}=-4.8 \times 10^{-2}\left(h / L_{0}^{*}=0.165\right) \sim \\
4.8 \times 10^{-2}\left(h / L_{0}=0.104\right) \%
\end{gathered}
$$

式(53)は簡易な形をとるにもかかわらず, 適用範囲内で の精度はかなり高い。

15) Wu and Thornton ${ }^{13)} の$ 第 1 式 (WT1 と略記)

$$
\begin{gathered}
k_{a} h=\alpha^{1 / 2}\left\{1+\frac{\alpha}{6}\left(1+\frac{\alpha}{5}\right)\right\} ; h / L_{0}^{*} \leq 0.219 \\
\tilde{\varepsilon}=-3.4 \times 10^{-2}\left(h / L_{0}^{*}=0.219\right) \sim 0\left(h / L_{0} \rightarrow 0\right) \%
\end{gathered}
$$

図 5 ( 14) 15)の各式による相対誤差 $\tilde{\varepsilon} と h / L_{0}$ の関 係を表す $\tilde{\varepsilon}$ はいずれの式によっても $h / L_{0}$ の増加ととも に極值をとつたのち，急増减する。

ついで, 浅海域に適用力限定される川グループの式の うち, 長い項をもつか精度も高い近似式，すなわち(2)グ ループに分類される式として You ${ }^{2)}$ 式, Venezian ${ }^{12)}$ の第
2 式 , Olson ${ }^{14)}$ の式のうち, $\mathrm{Venezian}^{12)}$ の第 2 式と炎の相対 誤差の範囲はつぎのようである .

16) Venezian ${ }^{12)}$ 第 2 式 (Vene2 と略記)

$$
\begin{gathered}
k_{a} h=\alpha^{1 / 2}\left(1+p_{1} \alpha+p_{2} \alpha^{2}+p_{3} \alpha^{3}\right) /\left(1+q_{1} \alpha+q_{2} \alpha^{2}+q_{3} \alpha^{3}\right) \\
; h / L_{0}^{*} \leq 0.159\left(\alpha^{*} \leq 1\right) \\
p_{1}=-0.42886826 \quad p_{2}=0.0939283 \\
p_{3}=-0.00269417 \quad q_{1}=-0.59553493 \\
q_{2}=0.16262861 \quad q_{3}=-0.01497505 \\
\tilde{\varepsilon}=-2 \times 10^{-4} \quad\left(h / L_{0}^{*}=0.159\right) \sim \\
6 \times 10^{-6}\left(h / L_{0}=0.030\right) \%
\end{gathered}
$$

式(57)は複杂隹な形をもつが , 光の精度は適用範囲内では 非常に高い．正の相対誤差は $h / L_{0}<0.1$ で実質的に $0\left(<10^{-5} \%\right)$ であり， $h / L_{0}>0.1$ で負の相対誤差が次第に 増大する .このため, 適用範囲を Venezian ${ }^{12)}$ が与えた $\alpha^{*} \leq 1\left(h / L_{0}^{*} \leq 0.159\right)$ としている.

（5）准深海域に適用力限定される近似式

॥11のグループに属し，准深海域に適用か限定される Nielsen ${ }^{15)}$ の第 3 式と Wu and Thornton ${ }^{13)}$ 第 2 式のうち , 後者の式と炎の相対誤差の範囲はつぎのように表される . 17) Wu and Thornton ${ }^{13)} の$ 第 2 式 (WT2 と略記)

$$
\begin{gathered}
k_{a} h=\alpha\{1+2 t(1+t)\}, \quad t=\exp \left\{-2 \alpha\left(1+1.26 e^{-1.84 \alpha}\right)\right\} \\
; h / L_{0}^{*} \geq 0.195 \\
\tilde{\varepsilon}=-2.5 \times 10^{-2}\left(h / L_{0}=0.252\right) \sim \\
2.5 \times 10^{-2}\left(h / L_{0}^{*}=0.195\right) \%
\end{gathered}
$$

この式の精度は比較的高いが 式の形がや複杂隹である． 浅海域に対して 14)〜16)のいずれかの式, 准深海域に 対して式(60)を用い，両者を接続すれば， $h / L_{0}$ の全範囲 に適用可能な近似式が得られる.Wu and Thornton ${ }^{13)}$ は $\alpha=0.4 \pi \quad\left(h / L_{0}=0.2\right)$ を境とする式(55)と式(60)の組合 せ，また You'(は別の組合せを提案している。しかし，た とえば Wu and Thornton ${ }^{13}$ による式(55)は光の接続境界で ある $h / L_{0}=0.2$ で $\tilde{\varepsilon}=-2.4 \times 10^{-2} \%$, 式(60)は $\tilde{\varepsilon}=1.6 \times$ $10^{-2} \%$ とり，両者の值は連続しない.

表- 1 は各近似式の相対誤差の範囲の一覧を改めて示 したものである.なお，紙数の都合上省略した Nielsen ${ }^{11)}$ の第 1 式と第 2 式,Nielsen ${ }^{15)}$ 第 3 式, You ${ }^{2}$ の式 ,Olson ${ }^{14)}$ の式に対する相対誤差の範囲は別途 ${ }^{16}$ 与えている.

\section{4. 結 語}

本研究では, 水深・深每波長比 $h / L_{0}$ の全範囲に有効な 近似式について，(1)Carvlho ${ }^{8}$ の第 5 式の修正式に対する 反復解 , すなわち山口・野中の第 9 式(45) (誤差範囲 \pm 
表-1 波長の近似計算式の相対誤差の範囲

\begin{tabular}{|l|l|l|}
\hline No. & formula & \multicolumn{1}{|c|}{ relative error $(\%)$} \\
\hline 1$)$ & Eckart & $0 \sim 5.24$ \\
\hline 2$)$ & Iwagaki & $-3.05 \sim 3.14$ \\
\hline 3$)$ & Carv14 & $-2.45 \sim 3.28$ \\
\hline 4$)$ & FM & $-1.39 \sim 1.66$ \\
\hline 5$)$ & YN1 & $-1.52 \sim 1.55$ \\
\hline 6$)$ & Carv9 & $-1.12 \sim 0$ \\
\hline 7$)$ & Guo & $-0.75 \sim 0.75$ \\
\hline 8$)$ & YN2 & $-0.73 \sim 0.73$ \\
\hline 9$)$ & Carv5 & $-0.21 \sim 0.27$ \\
\hline 10$)$ & Carv4 & $-0.12 \sim 0.20$ \\
\hline $11-1)$ & Fenton & $-5.1 \times 10^{-2} \sim 8.4 \times 10^{-3}$ \\
\hline $11-2)$ & YN3 & $-4.0 \times 10^{-2} \sim 1.2 \times 10^{-2}$ \\
\hline $11-3)$ & YN4 & $-2.9 \times 10^{-2} \sim 6.7 \times 10^{-3}$ \\
\hline $11-4)$ & YN5 & $-4.9 \times 10^{-3} \sim 4.9 \times 10^{-3}$ \\
\hline $11-5)$ & YN6 & $-4 \times 10^{4} \sim 1.4 \times 10^{-3}$ \\
\hline $11-6)$ & YN7 & $-1.2 \times 10^{-3} \sim 1.2 \times 10^{-3}$ \\
\hline $11-7)$ & YN8 & $-9 \times 10^{4} \sim 8 \times 10^{4}$ \\
\hline $11-8)$ & YN9 & $-1.1 \times 10^{4} \sim 1.1 \times 10^{-4}$ \\
\hline $11-9)$ & YN10 & $-7 \times 10^{-6} \sim 4 \times 10^{-5}$ \\
\hline 12$)$ & Hunt1 & $-7.0 \times 10^{-2} \sim 7.8 \times 10^{-2}$ \\
\hline 13$)$ & Hunt2 & $-8.2 \times 10^{-3} \sim 5.4 \times 10^{-3}$ \\
\hline 14$)$ & Vene1 & $\pm 4.8 \times 10^{-2}\left(h / L_{0}^{*} \leqq 0.165\right)$ \\
\hline 15$)$ & WT1 & $-3.4 \times 10^{-2} \sim 0\left(h / L_{0}^{*} \leqq 0.219\right)$ \\
\hline 16$)$ & Vene2 & $-2 \times 10^{4} \sim 6 \times 10^{-6}\left(h / L_{0}^{*} \leqq 0.159\right)$ \\
\hline 17$)$ & WT2 & $\pm 2.5 \times 10^{-2}\left(h / L_{0}^{*} \geqq 0.195\right)$ \\
\hline
\end{tabular}

$0.0001 \%)$

$k_{a} h=\left\{\alpha+\beta_{a}^{2}\left(1-\tanh ^{2} \beta_{a}\right)\right\} /\left\{\tanh \beta_{a}+\beta_{a}\left(1-\tanh ^{2} \beta_{a}\right)\right\}$, $\beta_{a}=\alpha \cdot \operatorname{coth}\left(m^{\alpha} \cdot \alpha^{1 / 2}\right) ; m=1.1965, \alpha=2 \pi h / L_{0}$

が適切であること，(2)やや低い 精度を許容する場合には Carvlho ${ }^{8)}$ の第 5 式(26)（誤差範囲- $0.21 \sim 0.27 \%$ )

$$
k_{a} h=\alpha \cdot \operatorname{coth}\left(1.2^{\alpha} \cdot \alpha^{1 / 2}\right), \quad \alpha=2 \pi h / L_{0}
$$

が十分利用可能であること，を示した .

また， $h / L_{0}$ に関して適用範囲をもつ近似式について， (1)浅海域を対象とする式は谷の項数や複杂隹さを増すほど 精度を向上させるが , 適用範囲外で急激な精度低下をも たらすこと，(2)浅海域および淮深海域を対象とするとれ
ぞれの式は誤差に関して異なる挙動をもつので, 両式の 接続によって $h / L_{0}$ の全範囲て整合性のある高精度近似 式を構成することか容易でないこと，を明らかにした． 結侖として , 波長の近似計算のためには, $h / L_{0}$ の全範囲 に適用可能な単一の式力望ましいと考えられる。

\section{参考文献}

1) Fenton, J. D. : The numerical solution of steady water wave problems, Computers \& Geosciences, Vol.4, No.3, pp.357-368, 1988.

2) You, Z. J. : Discussion of "Simple and explicit solution to the wave dispersion equation" [Coastal Engineering 45(2002) 71-74], Coastal Eng., Vol.48, pp.133-135, 2003.

3) Guo, J.: Simple and explicit solution of wave dispersion equation, Coastal Eng., Vol.45, pp.71-74, 2002.

4) 合田良実 : 海の波の波長計算プログラム, 土木学会論文報 告集, 第179号, pp.97-98, 1970 .

5) 合田良實 : 港湾構造物の耐波設計 (増補改訂)，鹿島出版 会, pp.173-175, 1990.

6) Eckart , C . : The propagation of gravity waves from deep to shallow water, National Bureau of Standards, Circular 521, Washington D. C., pp.165-173, 1952.

7) 岩坦雄一: 最新海岸工学, 森北出版, p.45, 1987.

8) http://www.filespoint.com/point/2069111//wave_29052006.pdf.h $\mathrm{tml}$

9) Fenton, J. D. and W. D. McKee: On calculating the lengths of water waves, Coastal Eng., Vol.14, pp.499-513, 1990.

10) Hunt, J. N. : Direct solution of wave dispersion equation, $J$. Waterway, Port, Coastal and Ocean Div., Proc. ASCE, Vol.105, No.WW4, pp.457-459, 1979.

11) Nielsen, P . : Explicit formulae for practical wave calculations, Coastal Eng., No.6, pp.389-398, 1982.

12) Venezian, G.: Discussion to the Paper by J. N. Hunt (1979), $J$. Waterway, Port, Coastal and Ocean Div., Proc. ASCE, Vol.106, No. WW4, pp.501-502, 1980.

13) $\mathrm{Wu}, \mathrm{C} . \mathrm{S}$. and E. B. Thornton : Wave numbers of linear progressive waves, J. Waterway, Port, Coastal, and Ocean Eng., ASCE, Vol.112, No.4, pp.536-540, 1986.

14) Olson, F. C. W. : An explicit expression for the wave length of a gravity waves, J. Phys. Oceanogr., No.3, pp.238-239, 1973.

15) Nielsen, P. : Explicit solutions to practical wave problems, Proc. 19th ICCE, Vol.1, pp.968-982, 1984.

16) Yamaguchi, M. and H. Nonaka : Comparative study of explicit solutions to wave dispersion equation, Annu. Jour. Eng., Ehime Univ., Vol.6, 2007 in CD-ROM.

(2006. 9. 30受付) 